\title{
Wojciech KAŹMIERCZAK*
}

\section{PROCESJA BOŻEGO CIALA Z TRADYCJĄ KWIETNYCH DYWANÓW W SPYCIMIERZU JAKO KRAJOWE DZIEDZICTWO NIEMATERIALNE}

Zarys treści: Bardzo ważnym elementem święta Bożego Ciała jest barwna procesja, która wychodzi poza mury kościoła. Do tradycji tego święta należą cztery ozdobione gałęziami z brzozy i kwiatami ołtarze oraz sypanie kwiatów pod stopy kapłana niosącego Hostię. W Spycimierzu rozwinął się wyjątkowo piękny zwyczaj układania dywanu z kwiatów o długości około $2 \mathrm{~km}$ na drodze przejścia procesji. Dekorowanie trasy stało się tutaj swoistym dziełem artystycznym, w którym bierze udział cała społeczność parafii. W artykule przedstawiono zaangażowanie lokalnej wspólnoty parafialnej i samorządu na rzecz wpisania Bożego Ciała z tradycją kwietnych dywanów w Spycimierzu na Krajową listę niematerialnego dziedzictwa kulturowego w 2018 r. Uniejów

Słowa kluczowe: niematerialne dziedzictwo kulturowe, kwietne dywany, Spycimierz,

\section{WPROWADZENIE}

Bardzo ważną częścią dziedzictwa narodowego, oprócz zabytków materialnych, jest sfera kultury, która stanowi część dorobku duchowego i społecznego ludzkości ${ }^{1}$. Zwyczaje, rytuały i obrzędy świąteczne są to żywe, niematerialne przejawy kultury, odziedziczone po przodkach i przekazywane kolejnym pokoleniom. Niematerialne dziedzictwo jest niezmiernie istotne w procesie kształtowania

* ks. Wojciech Kaźmierczak, proboszcz parafii Podwyższenia Krzyża Świętego w Spycimierzu w latach 2008-2017; od 4.11.2017 r. proboszcz parafii Niepokalanego Poczęcia NMP w Krzymowie, e-mail: wkazmierczak@diecezja.wloclawek.pl.

1 A.W. Brzezińska, Reifikacja dziedzictwa kulturowego w świetle Konwencji UNESCO z 2003 roku, „Nauka” 2013, nr 1, s. 109-128. 
tożsamości każdej grupy społecznej i jednostki. Przetrwanie dziedzictwa niematerialnego w jego wielkim bogactwie jest warunkiem utrzymania różnorodności kulturowej w obliczu postępującej globalizacji.

Do ochrony niematerialnego dziedzictwa kulturowego, potrzebne są inne środki od tych, wykorzystywanych do ochrony zabytków. Ważne jest utrwalenie, zachowanie i przekazanie tego dziedzictwa niematerialnego następnym pokoleniom. Działania mające na celu ochronę muszą zatem zawsze angażować wspólnoty i grupy, a w niektórych przypadkach także jednostki, które kultywują takie dziedzictwo. Społeczności same muszą brać udział w identyfikowaniu i definiowaniu niematerialnego dziedzictwa - to właśnie one decydują o tym, które praktyki stanowią część ich dziedzictwa kulturowego².

Szczególna rola w systemie ochrony niematerialnego dziedzictwa kulturowego przyznana została społecznościom lokalnym, uznanym za depozytariuszy tradycji oraz beneficjentów potencjalnych systemów wsparcia. Za społeczność lokalną uznaje się grupę społeczną, w której kontakty mają charakter bezpośredni, opierają się na współdziałaniu i podzielanym systemie wartości oraz norm³. Obiektem ochrony powinny być te społeczności, które są nośnikami żywej kultury niematerialnej, a zasadniczym celem zapewnienie kontynuacji tej kultury przez młode pokolenie. Wszelkie działania na polu ochrony powinny polegać na ostrożnym wsparciu wspólnot, grup i jednostek oraz wzmacnianiu praktyk, które są osłabione i istnieje ryzyko ich zaginięcia ${ }^{4}$.

Wartość niematerialnego dziedzictwa kulturowego dostrzeżona została przez UNESCO, które w 2003 r. uchwaliło Konwencję w sprawie ochrony tego dziedzictwa ${ }^{5}$. Nakreślone przez UNESCO dziedziny zostały po wejściu w życie Konwencji w naszym kraju (16 sierpnia 2011 r.) przeformułowane przez działający przy Ministerstwie Kultury i Dziedzictwa Narodowego Zespół ds. Niematerialnego Dziedzictwa Kulturowego, aby odzwierciedlały specyfikę polską.

Narodowy Instytut Dziedzictwa zaproponował system ochrony polegający na tworzeniu rejestrów najpierw na poziomie regionalnym (gdzie region oznacza przynależność administracyjną do konkretnego województwa), następnie najbardziej wartościowe zjawiska powinny zostać wpisane na tzw. Krajową listę prowadzoną przez Ministra Kultury i Dziedzictwa Narodowego, by później móc się starać o dokonanie wpisu na międzynarodową listę. Umieszczenie zjawiska/ tradycji na listach regionalnych i liście krajowej odczytywane może być jako no-

2 Tamże.

3 J. Bednarski, Grupa lokalna, [w:] Stownik etnologiczny. Terminy ogólne, red. Z. Staszczak, Poznań 1987, Państwowe Wydawnictwo Naukowe, s. 150-153.

4 S. Ratajski, Zagrożenia dziedzictwa niematerialnego wedtug Konwencji UNESCO z 2003 roku, [w:] Niematerialne dziedzictwo kulturowe: zakresy - identyfikacja - zagrożenia, red. J. Adamowski i K. Smyk, Wyd. Uniwersytetu M. Curie-Skłodowskiej, Lublin, 2015, s. 15-26.

5 Konwencja UNESCO $w$ sprawie ochrony niematerialnego dziedzictwa kulturowego, 17 października 2003, Paryż. 
bilitacja mieszkańców, służy także promocji dorobku kulturowego, a tym samym ma wpływ na wzrost potencjału turystycznego miejscowości (regionu).

Celem artykułu jest przedstawienie zaangażowania lokalnej wspólnoty parafialnej i samorządu na rzecz wpisania Bożego Ciała z tradycją kwietnych dywanów w Spycimierzu na Krajową listę niematerialnego dziedzictwa kulturowego. Źródłem materiałów są doświadczenia autora, proboszcza parafii w Spycimierzu, analiza akt parafialnych i gminnych, rozmowy z mieszkańcami oraz analiza publikacji naukowych w tym zakresie.

Spycimierz ${ }^{6}$ jest obecnie małą wsią położoną w odległości $2 \mathrm{~km}$ od Uniejowa, która jednak posiada historię sięgającą XII w. Miejscowość ta była początkowo siedzibą kasztelani, na początku XIV w. przeszła w ręce rycerskie, następnie stała się ośrodkiem klucza dóbr arcybiskupów gnieźnieńskich. Swoje znaczenie utraciła w XIV w. po przeniesieniu ośrodka dóbr biskupich do Uniejowa ${ }^{7}$. Dawna świetność Spycimierza jest wciąż żywa wśród jego mieszkańców, a wypracowana przez pokolenia tradycja kwietnych dywanów jest ważnym elementem tożsamości. Niestety w aktach parafialnych nie zachowały się informacje o początkach zwyczaju układania kwiatowych dywanów na Boże Ciało.

6 Jest to miejscowość o wyjątkowo długiej metryce historycznej, a w starszych dokumentach, publikacjach i na mapach występuje jako Spicimierz, Spicymierz lub Śpicimierz (np. Stownik Geograficzny Królestwa Polskiego i innych krajów słowiańskich, t. I-XVI, wyd. B. Chlebowski, F. Sulimierski, W. Walewski, Warszawa 1880-1902 (dalej: SGKP), t. 11, s. 109; A. Nadolski, Spicymierz nad Warta - średniowieczny zespół osadniczy, „Archeologia Polski” 1966, t. X, z. 2, s. 701-712; J. Dylik, Województwo ze stolica bez antenatów, ŁTN, Łódź 1971, s. 88). Obecna nazwa Spycimierz pojawiła się w dokumentach gminnych dopiero w końcu XX w. i jest konsekwentnie stosowana. Formalnie od 1980 r. nazwa miejscowości w brzmieniu „Spycimierz” pojawiła się w Zarządzeniu nr 15 Ministra Administracji, Gospodarki Terenowej i Ochrony Środowiska z dnia 10 lipca 1980 r. w sprawie ustalenia wykazu miejscowości w Polskiej Rzeczypospolitej Ludowej (Dz.Urz. MAGTiOŚ Nr 4 poz. 9). Wykaz miejscowości będący załącznikiem do Zarządzenia stanowił odrębne wydawnictwo wydane przy współpracy z Głównym Urzędem Statystycznym. Dokument ten narzucał obowiązek stosowania takiej nazwy w stosunkach publicznych. Takie brzmienie przypieczętował wykaz urzędowych nazw miejscowości i ich części ogłoszony rozporządzeniem Ministra Administracji i Cyfryzacji z dnia 13 grudnia 2012 r. w sprawie wykazu urzędowych nazw miejscowości i ich części, które ukazało się w Dzienniku Ustaw z 13 lutego 2013 roku (poz. 200). Jest to drugi wykaz zawierający wszystkie urzędowo ustalone nazwy miejscowości i ich części, jaki ukazał się w Polsce. W Encyklopedii Katolickiej, Towarzystwo Naukowe Katolickiego Uniwersytetu Lubelskiego, Lublin 2013, t. 18, s. 744-745, w spisie parafii podane są dwie nazwy: Spycimierz i Spicymierz.

7 Stownik Geograficzny Królestwa Polskiego i innych krajów słowiańskich, t. I-XVI, wyd. B. Chlebowski, F. Sulimierski, W. Walewski, Warszawa 1880-1902 (dalej: SGKP), t. 11, s. 109; T. Figlus, Rozwój układu ruralistycznego Spycimierza na tle dziejów osadnictwa w świetle badań geograficzno-historycznych $i$ archeologicznych, „Biuletyn Uniejowski”, 2015, t. 4, s. 73-94; T. Poklewski, Spicymierska wtość grodowa w średniowieczu: obraz gospodarczy, „Acta Archeologica Lodziensia" 1975, nr 24; A. Nadolski, Spicymierz nad Warta - średniowieczny zespót osadniczy, „Archeologia Polski” 1966, t. X, z. 2, s. 701-712. 


\section{WYJĄTKOWOŚĆ PROCESJI BOŻEGO CIAŁA W SPYCIMIERZU}

Uroczystość Najświętszego Ciała i Krwi Chrystusa (Boże Ciało) została wprowadzona do kalendarza liturgicznego w XIII w. aby ożywić i dowartościować kult Eucharystyczny ${ }^{8}$. W Polsce obchodzono ją po raz pierwszy w 1320 roku w diecezji krakowskiej9. Najbardziej widowiskowym elementem święta była i jest nadal barwna procesja, która wychodzi poza mury kościoła - na ulice wsi i miast. Informacje o procesjach pochodzą już z XIV w. z Anglii, Hiszpanii, Włoch i Francji ${ }^{10}$. Opisy procesji Bożego Ciała w XIV w. znane są także z Płocka i Wrocławia. W XV w. zwyczaj urządzania procesji w Boże Ciało przyjął się w całej Polsce i były one odprawiane zawsze bardzo uroczyście. W okresie zaborów, na ziemiach pod panowaniem pruskim i rosyjskim, wszelkie publiczne objawy uczuć narodowych były surowo prześladowane. Dlatego procesję Bożego Ciała organizowano z większym pietyzmem, jako jedyną sposobność zamanifestowania na zewnątrz nie tylko głębokiej wiary, ale także silnej łączności narodowej. W odrodzonej Polsce, po 1918 roku procesje były jeszcze bardziej okazałe.

Procesja Bożego Ciała nabiera specyficznego, wyróżniającego ją ze wszystkich innych procesji kościelnych, charakteru. Do tradycji tego święta należą cztery ozdobione gałęziami z brzozy i kwiatami ołtarze oraz sypanie kwiatów, pod stopy kapłana niosącego Hostię. Dodatkowo przyozdabiano całą trasę procesji, dlatego było to barwne wydarzenie ${ }^{11}$. W Kościele żywe kwiaty są wyrazem miłości do Zbawiciela i wdzięczności. Najbardziej powszechnym sposobem uszanowania i oddania czci Bogu było sypanie kwiatów przed niosącym Najświętszy Sakrament księdzem. Jest to zwyczaj we wszystkich częściach Polski. Z tego ogólnego schematu wyłamuje się procesja w Spycimierzu, gdzie do sypania kwiatków dołączono jeszcze układanie dywanów kwiatowych na drodze przejścia (ryc. 1, ryc. 2). Dekorowanie trasy procesji stało się tutaj swoistym dziełem artystycznym, w którym bierze udział cała społeczność parafii Spycimierz. Tradycja została przedstawiona nawet $\mathrm{w}$ publikacjach naukowych ${ }^{12}$.

8 A. Durak, Uroczystość Najświętszego Ciała i Krwi Chrystusa. Analiza hermeneutyczna tekstów celebracji, Poligrafia Salezjańska, Kraków 1999.

9 Z. Zalewski, Święto Bożego Ciała w Polsce do wydania Rytuału Piotrkowskiego (1621), „Studia z dziejów Liturgii w Polsce” 1973, t. 1, s. 95-162.

${ }_{10}$ Tamże.

${ }^{11}$ H. Zaremska, Procesja Bożego Ciała w XIV-XVI wieku, [w:] Kultura elitarna a kultura masowa w Polsce późnego średniowiecza, Wrocław-Warszawa-Kraków 1978.

${ }_{12}$ B. Ciesielska-Szynal, Dekoracje kwiatowe trasy procesji Bożego Ciała w Spicimierzu, „Sieradzki Rocznik Muzealny” 1996, t. 10, s. 31-40; A. Głaz, Boże Ciało w Spicymierzu, „Kronika Wielkopolski” 2005, nr 4 (116), s. 119-122; A. Różycki, Notatki z podróży po Polsce, „Polska Sztuka Ludowa. Konteksty" 1994, R. 48, nr 3-4, s. 122-126; A. Tomaszczuk, Kwietny kobierzec. O obchodach święta Bożego Ciała w Spycimierzu, „Konteksty. Polska Sztuka Ludowa” 2004, R. 58, nr 1-2, s. 213-220. 


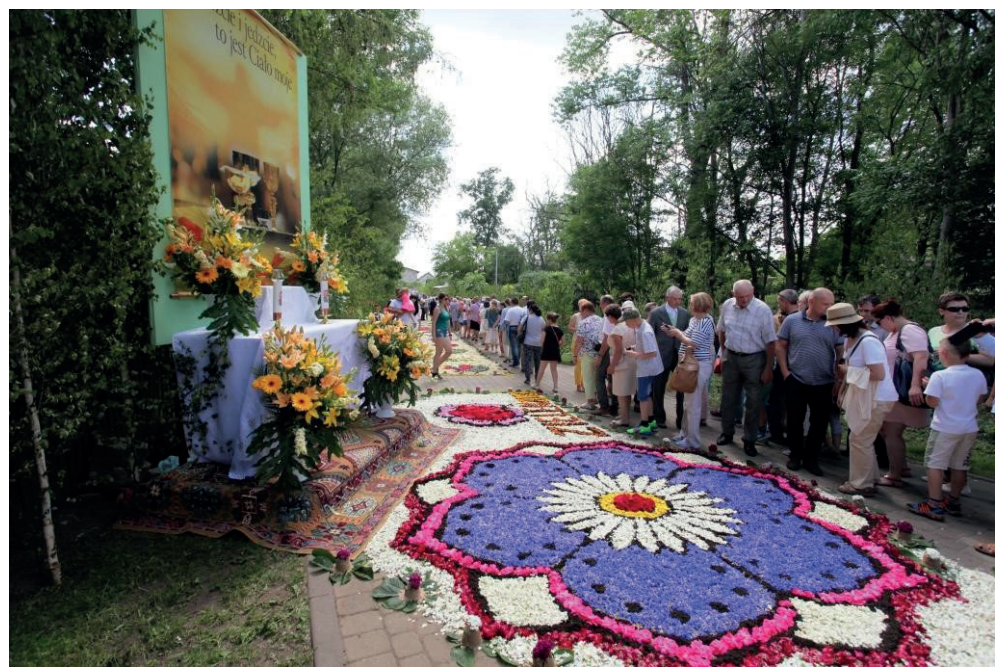

Ryc. 1. Udekorowana kwietnym dywanem trasa procesji w Spycimierzu Źródło: W. Kaźmierczak, 2017

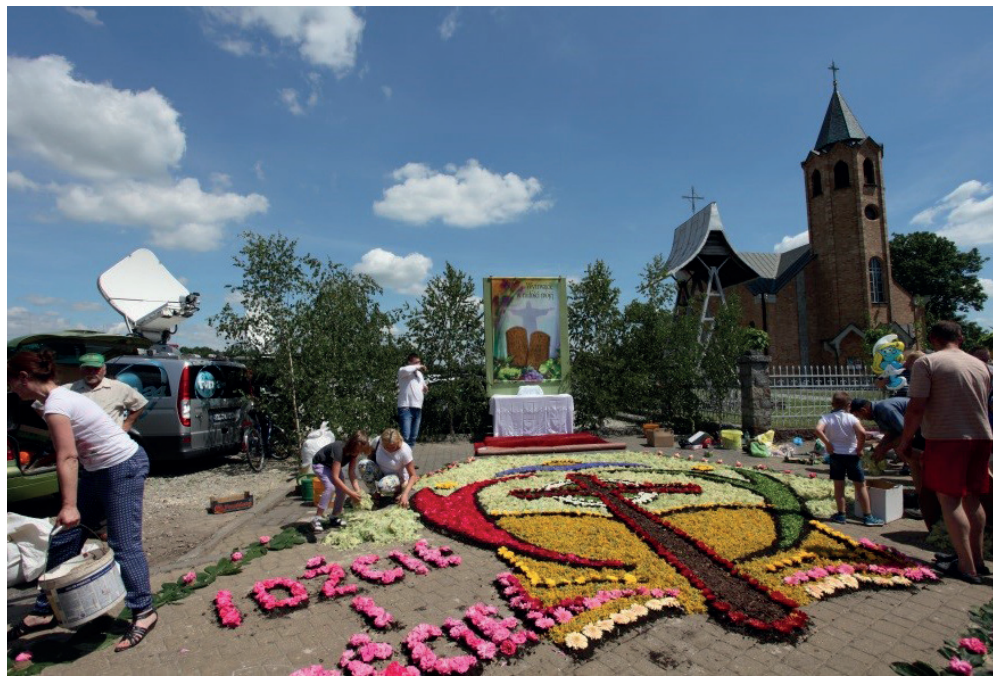

Ryc. 2. Mieszkańcy Spycimierza układający kwiatowy dywan Źródło: W. Kaźmierczak, 2017

Trudno jest dokładnie wskazać początki układania kwietnych dywanów ${ }^{13}$. Jak głosi miejscowa tradycja, zwyczaj ten przywędrował wraz z armią napoleońską w pierwszych latach XIX w. i zdominował swoją wyjątkowością dotychczasowe

${ }^{13}$ B. Ciesielska-Szynal, Dekoracje kwiatowe trasy procesji... s. 31-40. 
przyzwyczajenia mieszkańców wsi ${ }^{14}$. Próżno jednak szukać potwierdzenia tego faktu w kościelnych kronikach i innych pisanych dokumentach. $Z$ pewnością jednak zwyczaj ma ponad 100 lat, ale początkowo do dekoracji używano wyłącznie piasku i gałęzi drzew. W latach 20. XX w. wprowadzono kwiaty jako element dekoracyjny. Zwyczaj szczególnie mocno rozkwitł w latach 70-90. XX w. ${ }^{15}$ Trasę procesji o długości niemal $2 \mathrm{~km}$ zdobi misternie ułożony kwiatowy dywan o szerokości $2 \mathrm{~m}$ (ryc. 1, ryc. 2, ryc. 3, ryc. 4). W kompozycjach występują zarówno motywy roślinne, geometryczne, jak i religijne. Wzory układane są z różnokolorowych polnych i ogrodowych kwiatów (maki, chabry, jaśmin, łubin, akacja, rumianek, piwonie), z liści drzew, krzewów, mchów, i kory drzew. Użyte tu materiały nie mają jednak podtekstu symbolicznego są jedynie narzędziem do osiągnięcia właściwego efektu ${ }^{16}$.

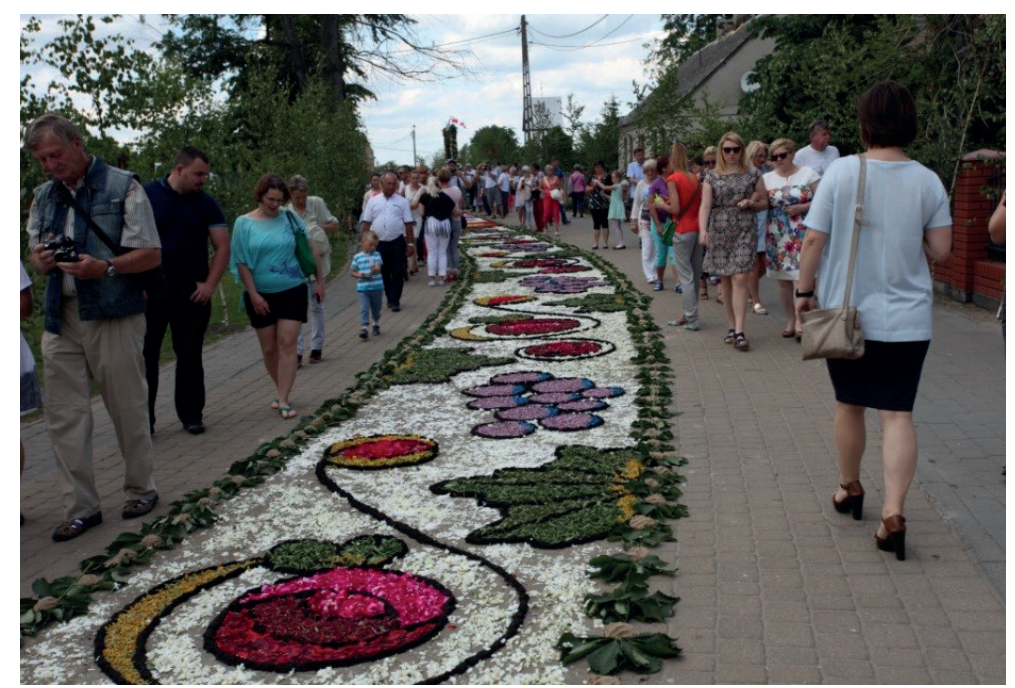

Ryc. 3. Kwietny dywan o szerokości dwóch metrów w Spycimierzu Źródło: W. Kaźmierczak, 2017

Kwiaty zbierane są zwykle od niedzieli poprzedzającej uroczystość i przechowywane w chłodnych pomieszczeniach. W poszukiwaniu kwiatów mieszkańcy jeżdżą nawet po kilkadziesiąt kilometrów. Ważny jest dobór kwiatów o intensywnych, trwałych kolorach. Rano w dniu Bożego Ciała mieszkańcy Spycimierza przystępują do układania kwiatowych kompozycji. Kobierce układają całe rodziny,

${ }^{14}$ J. Sobczak, Boże Ciało w Spycimierzu, [w:] Wielkopolska nasza kraina, Poznań 2004, t. III, s. 122-123, http://spycimierskiebozeciało.pl/pl/boze-cialo [dostęp: 28.06.2018].

${ }^{15}$ B. Ciesielska-Szynal, Dekoracje kwiatowe trasy procesji... s. 31-40.

${ }^{16}$ L. Rotter, Obecność kwiatów w światyni chrześcijańskiej (kilka uwag na marginesie), [w:] Symbolika roślin. Heraldyka i symbolika chrześcijańska, red. J. Marecki, L. Rotter, Kraków 2007, s. 201-217. 
często wielopokoleniowe, które odpowiadają za poszczególne fragmenty dywanu. O godzinie 17.00, gdy w innych parafiach jest już po procesji, rozpoczyna się uroczysta msza święta. Następująca po niej procesja eucharystyczna jest zwieńczeniem całego dzieła. W procesji biorą udział nie tylko mieszkańcy parafii, ale także wielu turystów. Jeszcze tego samego dnia po procesji, kwiatowe kompozycje są uprzątane. Te ulotne dzieła sztuki angażują całe rodziny nie tylko mieszkające w Spycimierzu, ale także w regionie. Kwietne dywany, zmieniając na kilka zaledwie godzin cały obraz wsi, są wyrazem marzeń o pięknie jej mieszkańców ${ }^{17}$.

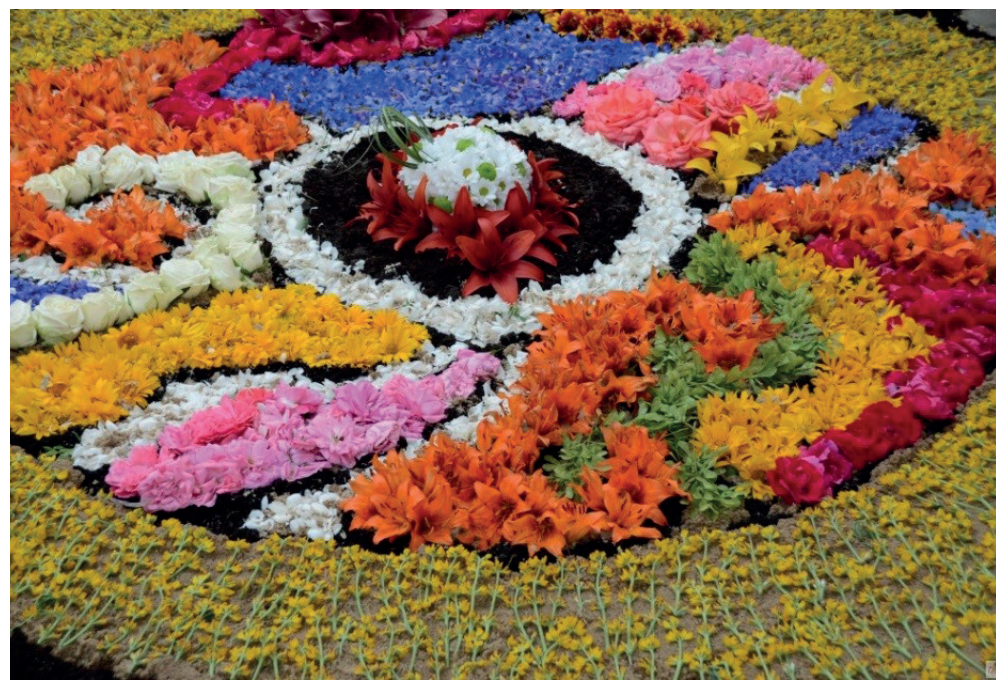

Ryc. 4. Fragment motywu z kwiatowego dywanu Źródło: W. Kaźmierczak, 2017

\section{OCHRONA TRADYCJI KWIETNYCH DYWANÓW JAKO NIEMATERIALNEGO DZIEDZICTWA KULTUROWEGO}

Zwyczaj układania kwietnych kobierców na święto Bożego Ciała w Spycimierzu jest bardzo ważny dla jego mieszkańców. Tworząc kompozycje kwiatowe, wykorzystują oni głównie własne zdolności, indywidulane poczucie rytmu, symetrii, równowagi kompozycyjnej i estetyki. Kwietne dekoracje podlegały przez kolejne dziesięciolecia wielu modyfikacjom i udoskonaleniom, dlatego obecnie mogą stanowić wzór dla innych ${ }^{18}$. W dobie globalizacji, która sprzyja ujednoliceniu sposobów zachowania i świętowania, istotne jest kultywowanie i zachowanie zwyczajów tak bardzo regionalnych, jakim są kwietne dywany w Spycimierzu.

${ }^{17}$ B. Ciesielska-Szynal, Dekoracje kwiatowe trasy procesji...
${ }_{18}$ Tamże. 
W marcu 2016 r. z inicjatywy proboszcza i mieszkańców parafii Spycimierz powstało Parafialne Stowarzyszenie „Spycimierskie Boże Ciało”. Stowarzyszenie ma charakter parafialny, ale jest nastawione na współpracę z innymi podmiotami. Od początku spotkało się z poparciem ze strony burmistrza gminy Uniejów i skorzystało z dużej pomocy pracowników gminy przy napisaniu statutu oraz załatwieniu formalności prawnych. Po dwóch miesiącach, dokładnie 2 maja 2016 r., zostało oficjalnie zarejestrowane w Krajowym Rejestrze Sądowym w Łodzi. Celem głównym Stowarzyszenia, jak stanowi statut, jest aktywne podtrzymywanie wśród parafian tradycji układania dywanów kwiatowych, dbanie o religijny wymiar i sakralny charakter uroczystych obchodów Bożego Ciała w Spycimierzu. Stowarzyszenie przyczynia się do większego włączenia całej wspólnoty parafialnej w tę piękną tradycję, z naciskiem na jej religijną symbolikę i chrześcijański wymiar.

Spycimierskie Stowarzyszenie było wzorowane na włoskich stowarzyszeniach kwiatowych zrzeszonych od $2002 \mathrm{r}$. w „Infioritalii” i jest odpowiedzią na aktualne potrzeby oraz prawne możliwości działalności społecznej. Stowarzyszenie postawiło sobie także cel wpisania „Bożego Ciała z tradycją kwietnych dywanów w Spycimierzu" na Krajową listę niematerialnego dziedzictwa kulturowego. Wiele osób podjęło trud przygotowania odpowiedniego wniosku do Ministra Kultury i Dziedzictwa Narodowego.

Przygotowanie wniosku wiązało się z podjęciem szeregu określonych działań przewidzianych przez Narodowy Instytut Dziedzictwa. Przede wszystkim nawiązano kontakt z wojewódzkim koordynatorem NID w Łodzi, panią Agnieszką Lorenc-Karczewską, która od początku wyraziła poparcie dla wniosku i służyła pomocą w dalszej części projektu. Od strony fachowej w przygotowaniu wniosku pomogli oddelegowani przez burmistrza Józefa Kaczmarka pracownicy gminy i specjaliści: przede wszystkim pan Andrzej Szoszkiewicz czuwający nad stroną formalną i historyk dr Piotr Szkutnik (pracownik Uniwersytetu Łódzkiego) badający archiwa państwowe i kościelne. Zebranie dokumentacji fotograficznej i wszelkich materiałów związanych z Bożym Ciałem w parafii Spycimierz należało do proboszcza i członków stowarzyszenia oraz parafian. Złożenie wniosku poparło również listownie kilkaset osób.

Od strony formalnej instytucją wnioskującą o dokonanie wpisu było Parafialne Stowarzyszenie „Spycimierskie Boże Ciało”. Osobą delegowaną do przeprowadzenia całego procesu był autor niniejszego artykułu. Po wielu miesiącach współpracy powstał wniosek o wpisanie Spycimierskiego Bożego Ciała na Krajową listę dziedzictwa niematerialnego, który został złożony przez proboszcza do Narodowego Instytutu Dziedzictwa w Warszawie. Wniosek otrzymał wysoką ocenę i Rada Instytutu zdecydowała o wpisaniu na elitarną krajową listę dziedzictwa niematerialnego. Decyzją wicepremiera, Ministra Kultury i Dziedzictwa Narodowego prof. dr. hab. Piotra Glińskiego z dnia 14 lutego 2018 r. „Procesja Bożego Ciała z tradycją kwietnych dywanów w Spycimierzu” została wpisana na Krajową listę niematerialnego dziedzictwa kulturowego. 
We wrześniu 2018 w Lublinie planowana jest uroczysta gala z wręczeniem przez ministra oficjalnie decyzji o wpisach na Krajową listę. Pod koniec lutego ministerstwo przesłało informację o wpisie na Krajową listę do parafii Spycimierz, a NID zamieścił informację na swojej stronie internetowej. Na stronie Narodowego Instytutu Dziedzictwa pośród dwudziestu kilku elementów tego dziedzictwa takich jak: Szopkarstwo krakowskie, Pochód Lajkonika czy Procesja Bożego Ciała w Łowiczu pojawił się również wpis dotyczący Bożego Ciała z tradycją kwietnych dywanów w Spycimierzu ${ }^{19}$.

W czasie obchodów rocznicy powstania stowarzyszenia parafialnego w lutym 2018 r. podjęto inicjatywę umieszczenia kwietnych dywanów na światowej liście niematerialnego dziedzictwa UNESCO. Pierwszy etap czyli wpisanie na krajową listę niematerialnego dziedzictwa kulturowego jest już zrealizowany.

Niewątpliwie sam wpis na Krajową listę jest wielkim sukcesem stowarzyszenia i docenieniem ogromnego wysiłku parafian spycimierskich, którzy tę pobożną tradycję przejęli od swoich przodków i tak pięknie ją rozwijają. Ale jest to dopiero pierwszy etap. Zgodnie z pomysłem burmistrza Józefa Kaczmarka, Parafialne Stowarzyszenie „Spycimierskie Boże Ciało” wraz z włoskimi stowarzyszeniami kwiatowymi rozpoczęło intensywne starania o wpisanie Bożego Ciała z tradycją kwietnych dywanów w Spycimierzu na światową listę dziedzictwa UNESCO. Jak dotąd na światowej liście niematerialnego dziedzictwa nie ma wpisu z Polski.

Oficjalnie to wspólne działanie zostało potwierdzone na walnym zebraniu włoskich stowarzyszeń kwiatowych Infioritalia w Rieti 17 marca 2018 r., w którym uczestniczyli przedstawiciele „Parafialnego Stowarzyszenia Spycimierskie Boże Ciało" z ks. Wojciechem Kaźmierczakiem i gminy Uniejów z burmistrzem Józefem Kaczmarkiem. Od roku zarówno prezes stowarzyszenia pani Maria Pełka, jak i ówczesny proboszcz parafii Spycimierz są członkami włoskiej Infioritalii. Władze samorządowe Uniejowa doceniają potrzeby i inicjatywy mieszkańców parafii. Od kilku lat starają się tak prowadzić inwestycje, aby zachęcić turystów do odwiedzania Spycimierza przez cały rok, a nie tylko w dzień Bożego Ciała.

\section{WNIOSKI}

Mieszkańcy małej parafii w Spycimierzu ukształtowali w ciągu dziesiątek lat wyjątkową tradycję układania kwietnych dywanów na Boże Ciało. Tradycja ta jest żywa i bardzo ważna dla mieszkańców nie tylko parafii, ale całej gminy Uniejów, a nawet Polski. Jest przykładem, jak ulotne kwiatowe dzieło - istniejące tylko kilka godzin w roku - jest w stanie zaangażować i zjednoczyć mieszkańców. Jest powodem dumy z tak wyjątkowego zwyczaju, ale także elementem jedno-

${ }^{19} \mathrm{http} / / /$ niematerialne.nid.pl/Dziedzictwo_niematerialne/Krajowa_inwentaryzacja/Krajowa_lista_NDK/ [dostęp: 25.05.2018]. 
czącym lokalną społeczność. Doprowadzenie do wpisania kwietnych dywanów w Spycimierzu na Krajowa listę dziedzictwa niematerialnego jest bardzo dobrym przykładem skutecznego postępowania i współpracy wielu interesariuszy. Najważniejsza była inicjatywa i zaangażowanie lokalnej społeczności - mieszkańców Spycimierza, następnie pomoc i wsparcie władz samorządowych Gminy Uniejów. Należy podkreślić, że w każdym takim przypadku nieoceniona jest praca i odpowiedzialność pojedynczych osób - w tym przypadku księdza proboszcza ze Spycimierza oraz moderatora wielu wydarzeń w gminie Uniejów. Do prac nad przygotowaniem wniosku włączone zostało także środowisko akademickie z Uniwersytetu Łódzkiego.

Można ocenić postępowanie, zmierzające do wpisania kwietnych dywanów na Krajową listę dziedzictwa niematerialnego, jako wzorcowe. Budowany system ma charakter oddolny, oparty na udziale oraz zaangażowaniu ludzi i społeczności lokalnych. Zgodnie z obowiązującym prawem, samorząd lokalny odpowiedzialny jest za ochronę nie tylko zabytków, ale także dziedzictwa niematerialnego. W celu naukowego opracowania materiałów z różnych źródeł, a także dokumentacji współczesnej tradycji zostało włączone środowisko akademickie.

W życiu człowieka ważna jest tradycja, czyli dziedzictwo niematerialne, którą należy właściwie zrozumieć i dostosować do współczesnych czasów. Każdy przejaw tego dziedzictwa jest cenny dla tych, którzy je praktykują i zapewnia im poczucie przynależności do wspólnoty. Wpis na listę niematerialnego dziedzictwa jest sprawą prestiżową, zachęca turystów do odwiedzania danego miejsca, przyczynia się także w dużym stopniu do wykorzystania wartości kulturowych w działaniach społecznych i ekonomicznych.

\section{Bibliografia}

Bednarski J., Grupa lokalna, [w:] Stownik etnologiczny. Terminy ogólne, red. Z. Staszczak, Państwowe Wydawnictwo Naukowe, Poznań 1987, s. 150-153.

Brzezińska A.W., Reifikacja dziedzictwa kulturowego w świetle Konwencji UNESCO z 2003 roku, „Nauka” 2013, nr 1, s. 109-128.

Ciesielska-Szynal B., Dekoracje kwiatowe trasy procesji Bożego Ciała w Spicimierzu, „Sieradzki Rocznik Muzealny" 1996, t. 10, s. 31-40.

Durak A., Uroczystość Najświętszego Ciała i Krwi Chrystusa. Analiza hermeneutyczna tekstów celebracji, Poligrafia Salezjańska, Kraków 1999.

Dylik J., Województwo ze stolica bez antenatów, Łódzkie Towarzystwo Naukowe, Łódź 1971.

Encyklopedia Katolicka, Towarzystwo Naukowe Katolickiego Uniwersytetu Lubelskiego, Lublin 2013, t. 18.

Figlus T., Rozwój układu ruralistycznego Spycimierza na tle dziejów osadnictwa w świetle badań geograficzno-historycznych i archeologicznych, „Biuletyn Uniejowski” 2015, t. 4, s. 73-94.

Głaz A., Boże Ciało w Spicymierzu, „Kronika Wielkopolski” 2005, nr 4 (116), s. 119-122. 
Konwencja UNESCO w sprawie ochrony niematerialnego dziedzictwa kulturowego, 17 października 2003, Paryż.

Nadolski A., Spicymierz nad Warta - średniowieczny zespół osadniczy, „Archeologia Polski” 1966, t. X, z. 2, s. 701-712.

Poklewski T., Spicymierska włość grodowa w średniowieczu: obraz gospodarczy, „Acta Archeologica Lodziensia" 1975, nr 24.

Ratajski S., Zagrożenia dziedzictwa niematerialnego wedtug Konwencji UNESCO z 2003 roku, [w:] Niematerialne dziedzictwo kulturowe: zakresy - identyfikacja - zagrożenia, red. J. Adamowski i K. Smyk, Wyd. Uniwersytetu M. Curie-Skłodowskiej, Lublin 2015, s. 15-26.

Rotter L., Obecność kwiatów w świątyni chrześcijańskiej (kilka uwag na marginesie), [w:] Symbolika roślin. Heraldyka i symbolika chrześcijańska, red. J. Marecki, L. Rotter, Kraków 2007, s. 201-217.

Różycki A., Notatki z podróży po Polsce, „Polska Sztuka Ludowa. Konteksty” 1994, R. 48, nr 3-4, s. $122-126$.

Stownik Geograficzny Królestwa Polskiego i innych krajów słowiańskich, t. I-XVI, red. B. Chlebowski, F. Sulimierski, W. Walewski, Warszawa 1880-1902, t. 11, s. 109.

Sobczak J., Boże Ciało w Spycimierzu, [w:] Wielkopolska nasza kraina, Poznań 2004, t. III, s. $122-123$.

Tomaszczuk A., Kwietny kobierzec. O obchodach święta Bożego Ciała w Spycimierzu, Konteksty. „Polska Sztuka Ludowa” 2004, R. 58, nr 1-2, s. 213-220.

Zalewski Z., Święto Bożego Ciała w Polsce do wydania Rytuału Piotrkowskiego (1621), „Studia z dziejów Liturgii w Polsce" 1973, t. 1, s. 95-162.

Zaremska H., Procesja Bożego Ciała w XIV-XVI wieku, [w:] Kultura elitarna a kultura masowa w Polsce późnego średniowiecza, Wrocław-Warszawa-Kraków 1978.

Zarzadzenie nr 15 Ministra Administracji, Gospodarki Terenowej i Ochrony Środowiska z dnia 10 lipca 1980 r. w sprawie ustalenia wykazu miejscowości w Polskiej Rzeczypospolitej Ludowej (Dz.Urz. MAGTiOŚ, nr 4, poz. 9).

[Artykuł wpłyną: maj 2018; akceptacja: czerwiec 2018]

\section{CORPUS CHRISTI PROCESSION AND FLOWER CARPETS IN SPYCIMIERZ AS INTANGIBLE NATIONAL HERITAGE}

\section{Summary}

An important element of Corpus Christi celebration is a procession which goes outside church premises and stops on the way at four altars decorated with flowers and birch trees. Traditionally, dried flower petals are being thrown down before the priest bearing the Holy Sacrament. In Spycimierz, there is a beautiful tradition of making $2 \mathrm{~km}$ long flower carpets along the route of the procession. Decorating the procession route has become a specific work of art, in which participates all the community of the parish of Spycimierz. The article highlights the engagement of the local community and government in actions aimed at entering in 2018 the Corpus Christi celebration including the tradition of flower carpets in Spycimierz on the National List of intangible cultural heritage.

Keywords: intangible cultural heritage, flower carpets, Spycimierz, Uniejów 